\title{
Methods of tilling under conditions of insufficient and unstable moistening during winter wheat cultivation
}

\author{
Julia Semenikhina ${ }^{1, *}$, Sergey Kambulov ${ }^{1}$, Galina Parkhomenko ${ }^{1}$, Andrey Boyko ${ }^{2}$, Svetlana \\ Ponomareva $^{2}$, Svetlana Shvedova ${ }^{2}$, Alexander Koltsov ${ }^{2}$, and Elzara Tsybenko ${ }^{2}$ \\ ${ }^{1}$ State Scientific Establishment «Agricultural Research Center «Donskoy», 14, Lenin st., 347740, \\ Zernograd, Russia \\ ${ }^{2}$ Don State Technical University, 1, Gagarin Square, 344003, Rostov-on-Don, Russia
}

\begin{abstract}
Acute deficit of soil moisture during the growing season of crops negatively affects the yield. Various tillage methods that are part of the technology (traditional and zero) of winter wheat cultivation affect the soil structure in the topsoil, forming the soil structure in such a way that it acquires the properties of accumulation and preservation of atmospheric moisture. Purpose of the study is to determine the method of soil cultivation that contributes into increase in winter wheat productivity and moisture preservation in the soil. The study of various tillage methods was carried out under the conditions of many years of stationary experience in leguminous crop rotation. Soil and climatic conditions over the years of research were taken into account. The researched processing methods that form the basis of the traditional cultivation technology and implement their tillage tools are: surface disc harrow B7T; small - combined unit KUM 4; dump - plow PN5-35. And cultivation of winter wheat by seeder of direct sowing WINTERSTEIGER Plotseed according to zero technology was studied, i.e. the main tillage was absent.
\end{abstract}

\section{Introduction}

Under conditions of insufficient and unstable moistening [1] of the soil of the southern regions of Russia, the yield of crops and their stability is determined by the presence of sufficient and available moisture for plants in the soil. Natural moisture supply is formed by atmospheric precipitation in the late autumn, winter and spring periods $[2,3]$.

The dynamics of soil moisture is ensured by such properties as moisture capacity, water permeability, water capacity, moisture evaporation and soil hygroscopicity. These properties themselves are largely determined by the soil structure, on which the stability of soil aggregation, porosity, aeration and water permeability depend. Soil plays a crucial role in the functioning of ecosystems [4-6]. Acute deficit of soil moisture during the growing season of crops negatively affects the yield [7]; therefore, it is advisable to structure the soil

\footnotetext{
*Corresponding author: semenixina1982@mail.ru
} 
in the topsoil using agrotechnological tillage techniques in such a way that their maximum accumulation occurs during atmospheric precipitation with subsequent conservation [8].

Choosing soil tillage system with traditional wheat cultivation technology, the desicion is relied on technical tool that has the main mechanical effect on the soil, designed to solve simultaneously number of problems: changing the composition of the arable layer [9] and its structural state to ensure optimal water-air and thermal modes; ensuring the optimal density of the arable layer; enhancing the effectiveness of nutrients by extracting them from deeper horizons of the soil and the impact on enhancing its microbiological activity; destruction of weeds; incorporation of stubble and fertilizer; destruction of pests and pathogens of plant diseases; fight against water and wind erosion. Distinctive feature of the wheat cultivation by the type of zero technology [10-12] is the complete failure of mechanical impact on the soil, with the exception of the operation of introducing seeds into the soil by ploughshare planter group of direct seeding. Distinctive feature of the zero technology is single exposure to the soil during the sowing period. The traditional technology of crop cultivation requires multiple impacts on the soil, distributed over time during the cultivation period, contributing to the soil preparation for sowing, and the sowing itself. Purpose of the study is: to determine the method of soil cultivation that contributes into increase in winter wheat productivity and moisture preservation in the soil.

\section{Materials and methods}

The study of various tillage methods was carried out under the conditions of many years of stationary experience in leguminous crop rotation. The cultivated crop is winter wheat, the predecessor is peas. The soil of the experimental field is ordinary calcareous loamy chernozem. Humus content in the topsoil layer is $3.2 \% ; \mathrm{pH}$ is $7.0 ; \mathrm{P}_{2} \mathrm{O}_{5}$ is 18.0 $23.5 \mathrm{mg} / \mathrm{kg} ; \mathrm{K}_{2} \mathrm{O}$ is $336-360 \mathrm{mg} / \mathrm{kg}$ of soil. Weather conditions during the growing season of winter wheat differed in the amount of precipitation and air temperature. So, in the 2016/2017 agricultural year, the amount of precipitation and the average daily air temperature were higher than the annual average by $124 \%$ and $110 \%$, respectively. In the $2017 / 2018$ agricultural year, precipitation fell unevenly by season, their amount was $102 \%$ of the norm, and the average monthly air temperature was higher than the long-term average (by 117\%). In the 2018/2019 agricultural year, there was slight excess of precipitation (106\% of the long-term norm) and an increased temperature regime of air during the growing season (127\% of the norm). The study took into account air temperature, since this indicator has a significant effect on the evaporation of soil moisture $[13,14]$.

According to traditional technologies and zero tillage cultivation main carried out in three replications by various methods using soil-cultivating units, that are shown in Figure 1. 


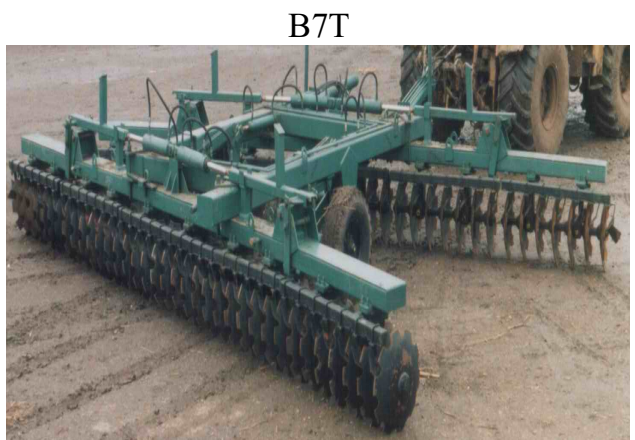

PN-5-35

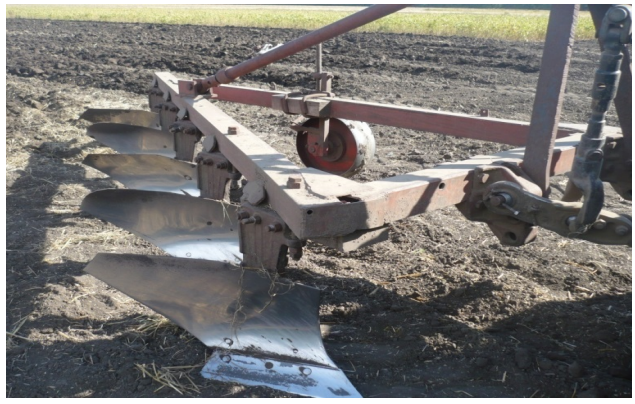

KUM-4

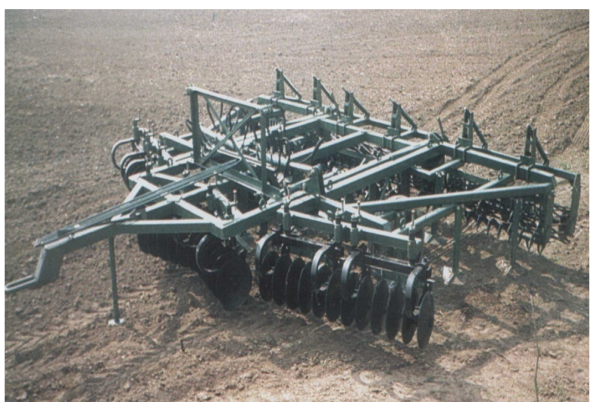

WINTERSTEIGER Plotseed

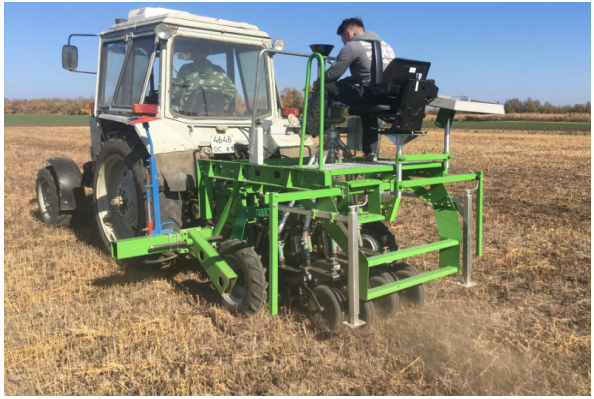

Fig. 1. Technical tillage devices.

For surface tillage to a depth of $8-10 \mathrm{~cm}, \mathrm{~B} 7 \mathrm{~T}$ disc harrow was used that performed only one operation of loosening by disk batteries. Small tillage was carried out to a depth of 12 $14 \mathrm{~cm}$ with the KUM-4 combined soil cultivating unit, which consists of battery of spherical disks, lancet feet, cultivator rollers, mulching rollers, which simultaneously carries out operations of loosening, crumbling blocks, combing ploughshare with subsequent leveling and compaction of the soil. Moldboard tillage to a depth of 23-25 cm was carried out with a PN-5-35 plow, which rotates the soil layer with moldboard bodies.

WINTERSTEIGER Plotseed two-disc ploughshares of direct seeding at had a cutting effect on the soil at the depth of seed application when cultivating winter wheat using zero technology[16-17].

Soil moisture was measured directly in the field. To do this, WaterScout SM 100 sensors were installed in the areas cultivated by various methods in the soil horizon at the depth of $30 \mathrm{~cm}$, which determine the soil moisture. The results of the indicators were recorded every one hour and were automatically recorded on the internal memory of the Watch Dog 1400 weather station recorder by Spectrum Technologies Inc (Figure 2).[18]

The use of autonomous recorder for recording moisture indicators with sensor tab made it possible to monitor the dynamics of moisture in the conditions of soil structure formation after the passage of tillage equipment. Archived data were removed from the built-in memory of the recorder once a month, while the soil in the area of the sensor remained intact, in order to avoid disturbance of the soil aggregation resulting from the applied tillage method [19-21]. 


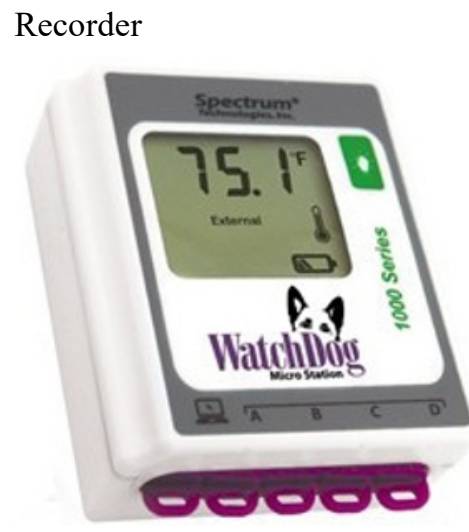

Soil moisture sensor

WaterScout SM 100

Fig. 2. Watch Dog 1400 Micro Weather Field Station with moisture sensor.

\section{Research results}

On average, during 2017-2019, the highest yield was recorded for zero technology (Table 1 ), with respect to which the change in the average the worst results wewre achievad for winter wheat productivity after small tillage by $12.14 \%$; after surface tillage yield declined by $8.37 \%$; the smallest yield difference was noted after moldboard tillage by $5.44 \%$.

Table 1. The results of the study on the winter wheat yield, depending on the methods of primary tillage, $\mathrm{t} / \mathrm{ha}$.

\begin{tabular}{|c|c|c|c|c|c|}
\hline \multirow{2}{*}{$\begin{array}{l}\text { The method of primary } \\
\text { tillage (technical tool) }\end{array}$} & \multicolumn{3}{|c|}{ Years of study } & \multirow{2}{*}{$\begin{array}{c}\text { Average } \\
\text { value, } t \text { / ha }\end{array}$} & \multirow{2}{*}{$\begin{array}{l}\text { Relatively to } \\
\text { average value, \% }\end{array}$} \\
\hline & 2017 & 2018 & 2019 & & \\
\hline \multicolumn{6}{|c|}{ Traditional cultivation technology } \\
\hline Surface tillage (B7T) & 8.63 & 5.43 & 5.64 & 6.57 & 91.63 \\
\hline Small tillage (KUM-4) & 7.23 & 5.63 & 6.05 & 6.30 & 87.86 \\
\hline $\begin{array}{l}\text { Moldboard tillage by PN-5- } \\
\text { 35) }\end{array}$ & 7.7 & 6.23 & 6.41 & 6.78 & 94.56 \\
\hline \multicolumn{6}{|c|}{ Zero cultivation technology } \\
\hline $\begin{array}{l}\text { WINTERSTEIGER Plotseed } \\
\text { planter of direct seeding }\end{array}$ & 8.48 & 6.27 & 6.75 & 7.17 & 100.00 \\
\hline $\mathrm{LSD}_{05}$ & 2.19 & 1.45 & 0.72 & - & - \\
\hline
\end{tabular}

At the same time, the actual difference between the tillage options when obtaining yield in 2017 and 2018 was less than the LCD (Lowest Significant Difference) - 2.196 and 1.45, respectively, which did not reveal their significant differences. However, in 2019 the differences between tillage options were significant, since the actual difference between the options was greater than LCD - 0.72 [22].

Analysis of the table data by years showed that weather conditions with insufficient soil moisture as a result of intensive evaporation due to high ambient temperatures contribute into decrease in wheat yield with surface and small methods of tillage [15], therefore, at soil moisture deficiency and adverse atmospheric conditions, the data processing methods should be applied in a limited form. Nevertheless, the weather favorable in 2017 made it possible to obtain high yields for the above treatments. As for the moldboard tillage method, it occupies middle position in the tillage methods during the three-year research period between surface and small methods and zero cultivation technology, where there is no tillage. Absolutely leading position in wheat productivity, regardless of weather conditions, was assigned to zero technology. Thus, untreated soil with the presence of crop 
residues on the field surface contributes into increase and preservation of productivity, which, in turn, is affected by high soil moisture. The obtained data on soil moisture are presented in Table 2.

Table 2. The results of the study of soil moisture depending on the methods of primary tillage during the growing season of winter wheat.

\begin{tabular}{|l|c|c|c|c|c|}
\hline \multirow{7}{*}{$\begin{array}{c}\text { The method of } \\
\text { primary tillage } \\
\text { (technical tool) }\end{array}$} & $\mathbf{2 0 1 7}$ & $\mathbf{2 0 1 8}$ & $\mathbf{2 0 1 9}$ & $\begin{array}{c}\text { Average } \\
\text { value, \% }\end{array}$ & $\begin{array}{c}\text { Relatively to } \\
\text { average value, } \\
\mathbf{\%}\end{array}$ \\
\cline { 2 - 6 } & \multicolumn{7}{|c|}{ Traditional cultivation technology } \\
\hline Surface tillage (B7T) & 43.6 & 42.2 & 41.4 & 42.4 & 87.2 \\
\hline Small tillage (KUM-4) & 42.8 & 46.4 & 39.9 & 43.0 & 88.5 \\
\hline $\begin{array}{l}\text { Moldboard tillage by } \\
\text { PN-5-35) }\end{array}$ & 44.5 & 48.3 & 41.6 & 44.8 & 92.2 \\
\hline \begin{tabular}{l} 
Zero cultivation technology \\
\hline $\begin{array}{l}\text { WINTERSTEIGER } \\
\text { Plotseed planter of direct }\end{array}$
\end{tabular} & 47.6 & 51.7 & 46.5 & 48.6 & 100.0 \\
\hline LSD $_{05}$ & 1.18 & 1.22 & 2.98 & - & - \\
\hline
\end{tabular}

On average, during 2017-2019, the highest soil moisture was recorded after zero technology (Table 2), with respect to which the change in the average value the worst soil moisture was obtained after surface tillage by $12.8 \%$; after small tillage decrease in humidity occurred by $11.5 \%$; the smallest difference in moisture content was noted after moulboard tillage by $7.8 \%$.[23]

At the same time, differences in soil moisture among the tillage options were significant, since the actual difference between the tillge options during studied years exceeded LCD: in 2017 - 1.18, 2018 - 1.22, in 2019 - 2.98.[24]

The analysis of data by years showed that the saturation of the soil with atmospheric moisture is extremely uneven due to the uneven distribution of precipitation over the years and phases of vegetation. The increased ambient temperature, which provokes intense evaporation, that was typical for the 2018 and 2019 years of the study, most affected the moisture content of the soil with such tillage methods as surface and small ones. The moulboard method of tillage had the most saving effect on soil moisture among all studied. Absolutely leading position in the accumulation and conservation of soil moisture was observed in untreated soil both annually and on average for three years of research.

Thus, the zero technology of winter wheat cultivation has demonstrated the best indicators for providing soil moisture. And in the traditional cultivation technology, the application of moldboard tillage method resulted in the best moisture content of the soil.

\section{Conclusion}

Long-term studies have been carried out on the impact of winter wheat cultivation technology with specific soil tillage methods on winter wheat productivity and on the conservation of soil moisture under conditions of insufficient and unstable moisture.

The results of the study are obtained, indicating that untreated soil, that is, zero cultivation technology, provides stable and high yield of wheat, and also ensures the conservation of soil moisture comparing to traditional cultivation method. The decrease in moisture content after surface tillage was $12.8 \%$; after small one it was equal to $11.5 \%$; after moldboard method it was $7.8 \%$ comparing with untreated soil. The study results of soil cultivation methods that form the basis of the traditional tillage technology revealed that the moldboard tillage ensures wheat productivity and preservation of soil moisture in 
the best way than surface and small soil tillage methods.

\section{References}

1. J. Wei, R.E. Dickinson, H. Chen, Journal of Hydrometeorology 9(6), 1364-1376 (2008) https://doi.org/10.1175/2008JHM955.1

2. O.A. Kryvobok, O.O. Kryvoshein, T.I. Adamenko, Ukrainian Hydrometeorological Journal 22, 64-79 (2018) https://doi.org/10.31481/uhmj.22.2018.07

3. B. Ehdaie, A.P. Layne, J.G. Waines, Euphytica 186, 219-232 (2012) https://doi.org/10.1007/s10681-011-0585-9

4. H. Vereecken, A. Schnepf, J.W. Hopmans, M. Javaux, and others, Vadose Zone J. Soil Science Society of America 15, 5 (2016) https://doi.org/10.2136/vzj2015.09.0131

5. C. Calzolaria, F. Ungaroa, N. Filippib, M. Guermandib, F. Malucellib, N. Marchib, F. Staffilanib, P. Tarocco, Geoderma 261, 190-203 (2016) https://doi.org/10.1016/j.geoderma.2015.07.013

6. K. Adhikari, A.E. Hartemink, Geoderma 262, 101-111 (2016) https://doi.org/10.1016/j.geoderma.2015.08.009

7. D. Helmana, I.M. Lenskya, D.J. Bonfilb, Field Crops Research 232, 11-23 (2019) https://doi.org/10.1016/j.fcr.2018.12.003

8. V.R. Akuraju, D. Ryu, B.George, Y. Ryu, K. Dassanayake, Agric For Meteorol 232, 489-499 (2017) https://doi.org/10.1016/j.agrformet.2016.10.007

9. Y. Fang, Y. Du, J. Wang, A. Wu, S. Qiao, B. Xu, S. Zhang, K.H.M. Siddique, Y. Chen, Front Plant Sci. (2017) https://doi.org/10.3389/fpls.2017.00672

10. H. Blanco-Canqui, S.J. Ruis, Geoderma 326, 164-200 https://doi.org/10.1016/j.geoderma.2018.03.011

11. A.R. Melland, D.L. Antille, Y. Dang, Soil Research 55(3) (2016) https://doi.org/10.1071/SR16136

12. Y. Dang, A. Balzer, M. Crawford, V. Rincon-Florez, H. Liu, A.R. Melland, D.L. Antille, S. Kodur, M. Bell, J. Whish, Y. Lai, N. Seymour, L.C. Carvalhais, P.M. Schenk, Environmental Science and Pollution Research 25(2), 1000-1015 (2018) https://doi.org/10.1007/s11356-017-8937-1

13. O. Miller, D. Helman, T. Svoray, E. Morin, D. J. Bonfil, Field Crops Research 231 (2018) https://doi.org/10.1016/j.fcr.2018.11.011

14. D. Helman, D.J. Bonfil, I. Lensky, Agricultural Water Management 211, 210-219 (2019) https://doi.org/10.1016/j.agwat.2018.09.043

15. G.G. Parkhomenko, S.I. Kambulov, A.V. Olshevskaya, A.S. Babadzhanyan, N.V. Gucheva, I.Y. Mekhantseva, IOP Conference Series: Earth and Environmental Science (2019) https://doi.org/10.1088/1755-1315/403/1/012144

16. S.I. Kambulov, I.V. Bozhko, A.V. Olshevskaya, MATEC Web of Conferences 224, 05022 (2018) https://doi.org/10.1051/matecconf/201822405022

17. Yu.A. Ivanov, V.I. Pakhomov, S.I. Kambulov, D.V. Rudoi, ICMTMTE 2018 MATEC Web of Conferences 224, 05023 https://doi.org/10.1051/matecconf/201822405023

18. A. Altybayev, A. Zhanbyrbayev, B. Meskhi, D. Rudoy, A. Olshevskaya, A. Prohorova, $\begin{array}{lllll}\text { E3S Web of } & \text { 135, } & 01078 & \text { (2019) }\end{array}$ https://doi.org/10.1051/e3sconf/201913501078 
19. B. Meskhi, B. Golev, V. Efros, D. Rudoy, A. Olshevskaya, V. Zhurba, Y. Chayka, E3S Web of Conferences 135, 01083 (2019) https://doi.org/10.1051/e3sconf/201913501083

20. J. Gerber, A. Zavaly, A. Gavrilov, A. Olshevskaya, N. Kiyan, IOP Conf. Series: Earth and Environmental Science 403, 012014 (2019) doi:10.1088/1755-1315/403/1/012014

21. Y. Lachuga, A. Soloviev, A. Matrosov, I. Panfilov, V. Pakhomov, D. Rudoy, IOP Conf. Series: Earth and Environmental Science 403, 012055 (2019) doi:10.1088/1755$1315 / 403 / 1 / 012055$

22. E. Zubrilina, I. Markvo, V.Novikov, A. Beskopylny, L. Vysochkina, D. Rudoy, A. Butovchenko, IOP Conf. Series: Earth and Environmental Science 403, 012063 (2019) doi:10.1088/1755-1315/403/1/012063

23. V. Zhurba, Y. Chayka, N. Gucheva, D. Ushakov, N. Ugrekhelidze, N. Kulikova, M. Egyan, E3S Web of Conferences 135, $01087 \quad$ (2019) https://doi.org/10.1051/e3sconf/201913501087

24. V.V. Ivanov, N.S. Dontsov, A.V. Kirichek, MEACS 2017: IOP Conference Series: Materials Science and Engineering 327 (2018) doi:10.1088/1757-899X/327/3/032025 